\title{
Influence of tribal councils in construction projects (in KwaMhlanga, Mpumalanga, South Africa)
}

\author{
Sithole SJ and Antoine F. Mulaba-Bafubiandi
}

\begin{abstract}
Line of authority comes from many angles during construction projects in rural areas, and one such angle is traditional councils. The traditional rule is significant in most part of rural South Africa, thus their level of authority before, during and after the project was worth researching. The problem that is often encountered during such projects is when traditional councils put forward demands and systematic control measures that affect the project duration, finances and sometimes work quality. The research employed both the quantitative and qualitative approaches but leaned more on the customised qualitative approach due to the social nature of the research. Research looked at eight factors of influence by tribal councils which were explored through questionnaires amongst four subpopulation groups (stratum), namely; Community, Local municipality, Traditional councils and Professionals. The questionnaire used a Likert scale concept, which contained a verification exercise of repeating questions indirectly. The scale was from one to ten, with one indicating "Strongly Disagree" and ten indicating "Strongly Agree". Due to the employment of a qualitative approach in the research, Microsoft Excel and Statistical Package for the Social Science (SPSS) were used for capturing and analysing the data. The mean score of all factors of influence for the Community and Tribal council groups were above neutral, showing a clear agreement to the hypothesis by these groups. For most factors of influence, the Municipality and Professionals groups were neither in agreement or disagreement. The results produced correlate with the research hypothesis as strong evidence of influence by tribal councils was found, accompanied by an understanding of areas of influence. Limited literature gap in the engineering management field about the understanding of stakeholders, in particular tribal councils, should be widened to improve the delivery process of engineering projects, especially those done in rural areas.
\end{abstract}

Keywords - councils, construction projects, factors of influence, subpopulation groups

\section{INTRODUCTION AND BACKGROUND}

In construction, the success of a project relies upon how well the project team manages the works progress in relation to internal and external risks associated with the project. Over time, construction projects have become increasingly risky and dynamic in nature due to their size and complexity. Parallel to the aforementioned, the location where the project is taking

Sithole SJ, Master Student, Mineral Processing and Technology Research Centre, Department of Metallurgy, School of Mining, Metallurgy and Chemical Engineering, Faculty of Engineering and The Built Environment, University of Johannesburg, South Africa.

Antoine F. Mulaba-Bafubiandi University of Johannesburg, South Africa. place has a great influence to the project's social, environmental and economic aspects. Commonly the environmental and economic issues are usually a priority during the construction phase of a project due to an assumption that the social issues were incorporated during feasibility studies and that the final constructed product ought to address them. Social issues include; wellbeing of project end-users and cultural practices of people in that particular area where the project is taking place. In rural South Africa and in Africa in general, cultural practices are still of great importance and they are dominant in communal lands where the traditional leadership structure still reigns.

\section{RESEARCH FRAMEWORK}

In addressing inequality and giving rural people access to basic human needs the government of South Africa and investors are hard at work with rural projects, particularly road construction projects as means to connect the developed areas with rural communities. The lines of authority during the course of seeing these projects come to reality are many. Traditional councils form part of stakeholders with power and authority in rural projects. The demands put out by traditional councils are for the benefit of local communities and in other cases, for the sole benefit of the traditional ruler. Any deviations, with regards to meeting the aforementioned demands, by the project team can result into hostile situations with traditional councils. This then lead to unpleasant working conditions, community strikes, escalated demands, and in other cases, project termination if no mutual agreement is reached. An investigation with the main aim of helping governments, investors, project managers and all relevant stakeholders understand the position and influence of traditional councils in rural projects in order to mitigate possible collusions and project disturbances that can come as a result of being misinformed was conducted. Keeping in mind the principal objectives that include: managing line of authority during projects, maintaining mutually benefiting relationships with traditional councils, controlling project costs associated with the influence of traditional councils and maximising access to resource availability attainted through traditional councils.

\section{DOCUMENTED ACUMEN}

Rural construction projects are often small and common in terms of scope but are quite numerous because of a need for development in rural areas (Tran et al., 2014:2). These 
geographically dispersed projects are often complex in nature because of limited resources, lack of adequate construction management expertise, unique risk factors, and lack of sound liaison strategies will local communities. In their research, Wiegand and Maze (2009:7) found that lack of effective management of the construction projects often result in cost overruns, project terminations, poor quality, injuries and in some cases rework. Furthermore, Tran et al., (2014:7) picked up that issues associated with documentation, staffing, remote location, small local constructors, environment and communication further contribute to undesired project hindrances.

The poor communication methods between the local communities and construction project teams are a common subject in African countries because of a number of factors which include language barriers and the lack of understanding of the project by the local communities. This often leads to lack of full participation and project support by the locals ( $\mathrm{Li}$ and Niu, 2009: 1440). The local traditional councils have major influence in terms of controlling projects that often take place in their respective areas. To ensure that the project run smoothly in terms of support, the project team has to put in place an effective liaison system between the local traditional councils, authorities, NGOs, local municipalities, and the local community, (Qi and Li, 2010: Results and analysis, para. 3). Ramli et al., (2017: 2) revealed that out of 359 projects in Malaysia, 79.5 percent and 66.7 percent of the public and private projects were not completed within the time specified in the contracts. The major issue that causes delays was found to be lack of effective communication systems between contractors and local communities.

One of the poor communication symptoms is a lack of understanding of the project deliverables by local communities. In such instances, communities often lack the understanding of how to manage and support the product delivered by the project (Xiaoqin et al., 2010). Because of imperfect supervision and management system, the quality of rural drinking water project construction is relatively poor, which seriously affects project benefits (Zhenhua, 2013: 74). This brings forward an importance of bringing on board an effective community participation process that will keep the local community on a loop at all project stages.

The backbone of any project is finance. The ability of a client (financing agency) to finance the project from start to finish is a critical factor (Yun-Fei and Yun, 2009: 447). A part of project money, must be specially put aside for local community support and funding, directly or indirectly (Marrero et al., 2017: 2). Due to apartheid injustices that occurred in the 1900s in South Africa, community funding has gone to a point where policies have been put in place to compel clients to fund or support small local contractors and communities. Traditional councils often have influence on how that community funding has to be managed.

Rural development projects have a tendency of achieving their objectives in some areas (i.e domestic water supply, irrigation systems and road construction), however they often fail to adequately meet their objectives in other areas. Rural development projects find it hard to meet expectations in terms of regional development (Acharya, Yong Kim and Dai Lee, 2004: 5) and other several activities such as woman programs, forestry, animal husbandry, and creating additional income sources (Matejka and Sabart, 2018: 828). Berk and Akdemir's (2006: 1897) research study found some of the important reasons why entrepreneurs could not benefit from the Yozgat Rural Development Project and they are depicted on the pie chart below.

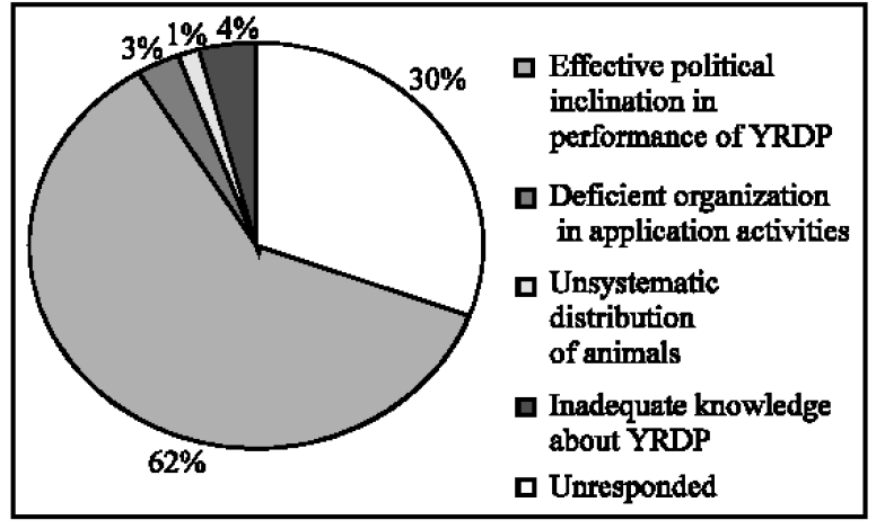

Fig. 1: Reasons why entrepreneur could not benefit from the YRDP (Berk and Akdemir, 2006:1897)

The results depicted on the pie chart suggests that political influence is a major reason why contractors and local community entrepreneurs can benefit or not benefit when there is a project in that particular area. Traditional community leadership has the same level of influence as those of politicians in activities that take place in rural communities (Licai and Baotong, 2008: 44), and thus, conducting a research study on the traditional leadership and their extent of influence is essential.

\section{RESEARCH APPROACH AND METHOD}

To address the set research questions, a customised qualitative approach was utilised because from previous literature it was noted that this approach is ideal for a research that looks at capturing expressive information of participants about their surroundings and sometimes experiences, which is highly impossible to convey though quantitative data. In conjunction to the selected approach, the following framework was applied to complete the research; 


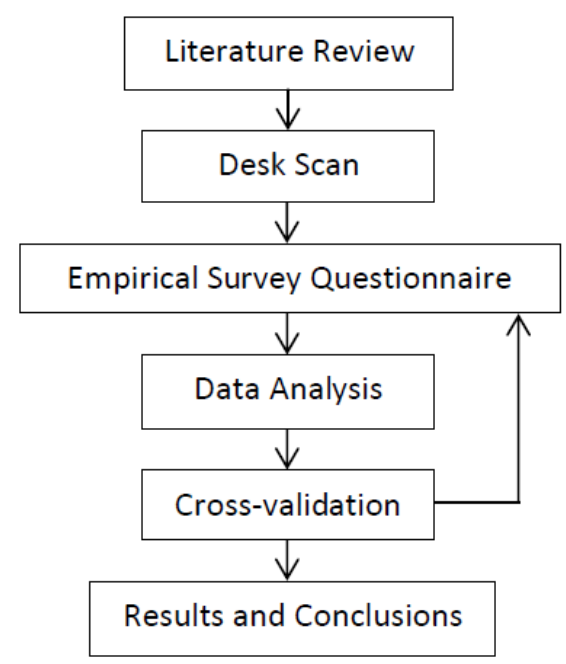

Fig. 2: Flow diagram of the research approach and method used in this investigation

A desk scan involved researching and processing literature associated with stakeholder management for projects that take place in rural areas and also contacting relevant stakeholders to obtain detailed information about specific projects. This research looked at eight factors of influence by tribal councils, which were presented to participants in a form of a questionnaire that used a Likert scale concept. The questions contained in the questionnaire were indirectly repeated for verification purposes. The scale was from one to ten, with one indicating "Strongly Disagree" and ten indicating "Strongly Agree" as tabulated on table 1.

TABLE I: RATING RANGE ON THE LIKERT SCALE

\begin{tabular}{|c|c|c|c|c|c|c|c|c|c|}
\hline \multicolumn{2}{|c|}{ Strongly disagree } & \multicolumn{2}{|c|}{ Disagree } & \multicolumn{2}{|c|}{ Neutral } & \multicolumn{2}{|c|}{ Agree } & \multicolumn{2}{|c|}{ Strongly agree } \\
\hline 1 & 2 & 3 & 4 & 5 & 6 & 7 & 8 & 9 & 10 \\
\hline
\end{tabular}

The factors were compiled by identifying key components that are critical for the success of projects, consultation with industry expects and reference to previous literature. The factors listed below were considered, namely project cost and duration, local resource availability, environmental issues, regulatory initiatives and authority, job creation or access, stakeholder coordination, social responsibility, and beneficiation of locals. Data was collected by soliciting responses from four subpopulation groups, namely; Community (400 participants), Local municipality (20 participants), Traditional councils (20 participants) and Professionals (20 participants). The population size is based on statistical power and the expenses of data collection. The simple random sample technique was applied because from previous studies, it has been found to be unbiased and at any stage during the sampling process each individual has the same probability of being chosen again. Data analysis was mainly done using the data analysis tool called Statistical Package for the Social Science (SPSS) because of the qualitative approach that was employed. Microsoft Excel was utilised for data capturing and checking of results produced by the SPSS data analysis tool.

\section{RESEARCH FINDINGS AND DiSCUSSIONS}

When all factors of influence were analysed for the four sub-population groups the mean, standard deviation, median, and mode were computed for each group. The overall mean responses of each group were also computed and are presented in the graph below.

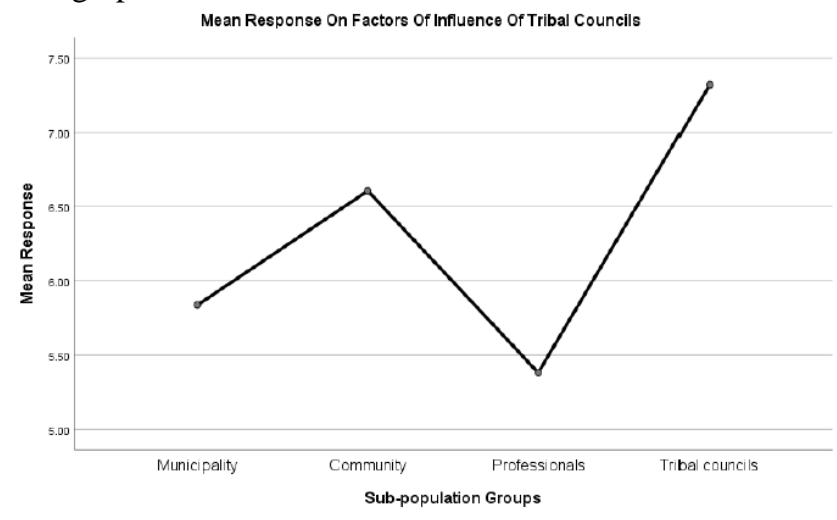

Fig. 3: Mean response of factors of influence of tribal councils (Groups)

The findings derived from Figure 3 indicate that the Municipality and Professionals groups are neutral about whether the tribal councils are influential or not. The community and the tribal councils groups were clear about their point of view, suggesting that the tribal councils have influence in construction projects that take place in rural areas.

Two of the four groups studied were of interest due to their general stance as portrayed in Figure 3. The descriptive data of these groups, table 2, show that Professionals are the group with the least mean, indicating least support for the ideology of tribal councils being influential. From the mean scores in table 2 , it is clear that Professionals feel that tribal councils have no much influence when it comes to "Project cost and duration" and Environmental issues. On the other hand the responses from the community suggest that they believe that tribal councils have an influence in construction projects. This further reinforced by the consistency of the descriptives in the responses from the community.

TABle II: Mean, StD.DEV, Median AND Mode (Professionals AND COMMUNITY)

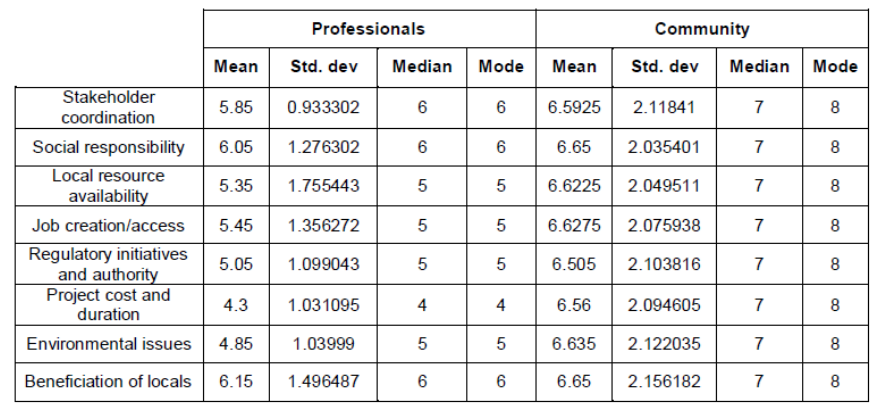

An analysis was performed on the data, this time testing the variance of mean values for all four groups using the overall mean of each factor in each group. Table 3 shows the overall factor perception data for each sub-population group. 


\begin{tabular}{|c|c|c|c|c|c|c|c|c|}
\hline \multicolumn{9}{|c|}{ TABLE III: DESCRIPTIVES } \\
\hline & \multirow{2}{*}{$\mathrm{N}$} & \multirow{2}{*}{ Mean } & \multirow{2}{*}{$\begin{array}{c}\text { Std. } \\
\text { Deviation }\end{array}$} & \multirow{2}{*}{$\begin{array}{l}\text { Std. } \\
\text { Error }\end{array}$} & \multicolumn{2}{|c|}{$\begin{array}{l}\text { 95\% Confidence } \\
\text { Interval for Mean }\end{array}$} & \multirow{2}{*}{ Minimum } & \multirow{2}{*}{ Maximum } \\
\hline & & & & & $\begin{array}{l}\text { Lower } \\
\text { Bound }\end{array}$ & $\begin{array}{l}\text { Upper } \\
\text { Bound }\end{array}$ & & \\
\hline Municipality & 8 & 5.838 & 1.02147 & 0.36114 & 4.9835 & 6.6915 & 4.3 & 7.25 \\
\hline Community & 8 & 6.605 & 0.05063 & 0.0179 & 6.563 & 6.6476 & 6.51 & 6.65 \\
\hline Professionals & 8 & 5.381 & 0.63524 & 0.22459 & 4.8502 & 5.9123 & 4.3 & 6.15 \\
\hline Tribal councils & 8 & 7.319 & 0.11934 & 0.04219 & 7.219 & 7.4185 & 7.1 & 7.5 \\
\hline Total & 32 & 6.286 & 0.94617 & 0.16726 & 5.9446 & 6.6268 & 4.3 & 7.5 \\
\hline
\end{tabular}

An investigation of the collected data showed that it was normally distributed with over 65 percent of values within one standard deviation from the mean. A one-way ANOVA test was computed to compare the means of the factors affecting the influence of tribal councils. Table 4 and 5 provides the results of the Homogeneity of Variances and the ANOVA test. From the ANOVA test, a significantly low Sig. value (below 0.05) was found, implying that there is a statistically significant difference between the means of at least two of the eight variables at the 95 percent confidence level. This is expected as the variables are independent and the perceptions vary with each factor.

\begin{tabular}{l|c|c|c|c}
\multicolumn{4}{c}{ TABLE IV: HomOGENEITY TEST OF VARIANCES } \\
& $\begin{array}{l}\text { Levene } \\
\text { Statistic }\end{array}$ & df1 & df2 & Sig. \\
\hline Based on Mean & 9.95 & 3 & 28 & 0.000 \\
\hline Based on Median & 8.565 & 3 & 28 & 0.003 \\
\hline $\begin{array}{l}\text { Based on Median and } \\
\text { with adjusted df }\end{array}$ & 8.565 & 3 & 11.934 & 0.003 \\
\hline $\begin{array}{l}\text { Based on trimmed } \\
\text { mean }\end{array}$ & 10.061 & 3 & 28 & 0.000 \\
\hline
\end{tabular}

TABLE V: ANOVA TABLE FOR FACTORS OF INFLUENCE BY TRIBAL COUNCILS $(\mathrm{N}=460)$

\begin{tabular}{lc|c|c|c|c} 
& $\begin{array}{c}\text { Sum of } \\
\text { Squares }\end{array}$ & df & $\begin{array}{c}\text { Mean } \\
\text { Square }\end{array}$ & F & Sig. \\
\hline Between Groups & 17.506 & 3 & 5.835 & 15.947 & 0.000 \\
\hline Within Groups & 10.246 & 28 & 0.366 & & \\
\hline Total & 27.752 & 31 & & & \\
\hline
\end{tabular}

Two of the ten pairs of survey questions were for checking the participants' awareness of tribal councils that exist in the KwaMhlanga (area of interest for this research) and the other checking whether or not participants supported the existence of tribal councils.

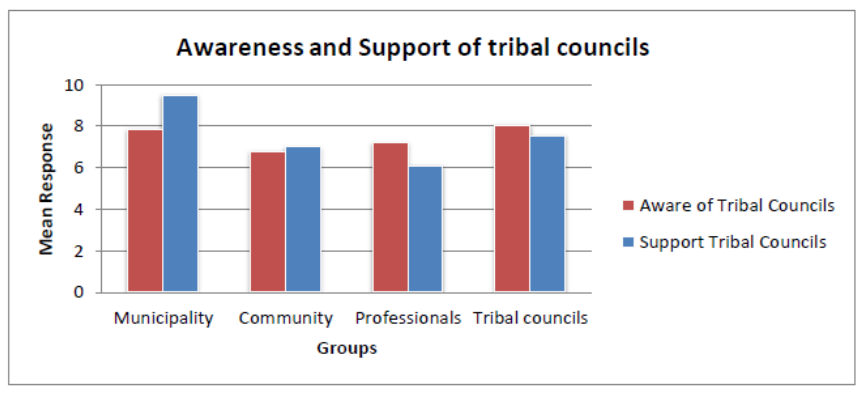

Fig. 4: Awareness and support of tribal councils

As shown on Figure 4, the mean score of support for the existence of tribal councils by the Municipality group stood out as it surpassed that of the Tribal Councils group, who were expected to support their existence much greater than other groups. The professionals showed the least support for the existence of tribal councils which directly relates to their low mean score as shown in Figure 3 which represents the perception of the different groups regarding the influence of tribal councils on construction projects.

\section{CONCLUSION}

The perceptions of the groups showed that the community and the traditional councils groups feel strongly about the traditional councils being influential in construction projects, whereas the Municipality and the Professionals are neutral in the matter. This research does not report actual quantitative project outcomes, and does not seek to validate the perceptions of the groups studied, but rather report the actual perceptions of these groups as they have been observed. The research outcomes will assist relevant stakeholders to appropriately manage their relationship with tribal councils in order to achieve minimal construction project hindrances that sometimes occur as a result of resistance by tribal councils. The study at hand looked at different factors of influence which is helpful to any relevant stakeholder to know what to expect and manage when dealing with traditional councils. There is little contribution from this study on measures that can be applied to manage destabilised relationships with traditional councils, which then opens an opportunity for further research in relation to tribal councils and stakeholder management in general.

\section{ACKNOWLEDGMENT}

The authors would like to thank the Ndebele tribal councils, community and Thembisile Hani local municipality for supporting this study. Special thanks to the professionals that participated in the study and those who provided expert support. One of the authors (AFM-B) has been supported by the University of Johannesburg Research Committee through the support to the Mineral Processing and Technology Research Centre and by the National Research Foundation as Rated scientist. The above supports are acknowledged..

\section{REFERENCES}

[1] Bingham, E., El Asmar, M., \& Gibson Jr, GE. (2018). “Project Delivery Method Selection: Analysis of User Perceptions on Transportation Projects" . Journal of Construction Engineering and Management. Vol. 144 , Issue 6.

[2] ArcGIS, Accessed, Accessed $01 \quad$ February 2019 "https://www.arcgis.com/home/webmap/viewer.html?layers=7acce354d aaa4a3ea9d83dcaf64cd70d"

[3] SPSS TUTORIALS, Accessed 20 November 2018 "https://www.spss-tutorials.com/spss-data-analysis"

[4] Wiegand, J. D., and Maze, T. H. (2009). "Strategy implementation by state transportation agencies to maintain work zone mobility and safety. Transportation Research Record 2107, Transportation Research Board, Washington, DC, 3 - 13. https://doi.org/10.3141/2107-01

[5] Li GZ \& Niu SW. (2009). Assessment of environmental and economic costs of rural household energy consumption in Loess Hilly Region, Gansu Province, China. Renewable Energy, 34: 1438 - 1444. https://doi.org/10.1016/j.renene.2008.10.018

[6] Xiaoqin,L, Jifu, Y \& Wenchao, L. (2010). In Modern water-saving and efficient agricultural and ecological Irrigation District Building, volume 2, Yunnan University Press

[7] Acharya N K, Yong Kim S \& Dai Lee Y. (2004). Factors affecting timely completion of construction projects Proceedings of the Fifth Asia Pacific Industrial Engineering and Management Systems Conference $2004 \mathrm{p}$ 22.4.1-13 
[8] Licai, G \& Baotong, Z. (2008).Efficiency of rural construction land consolidation base on increase and decrease connection of urban and rural construction land-for example of Taicang Jiangsu province. Rural Economy.10,pp.42-45,73

[9] Matejka, P \& Sabart, D. (2014). "Categorization of clashes and their impacts on construction projects" . Engineering for rural development. Czech Technical University in Prague, Czech Republic. DOI: 10.22616/ERDev2018.17.N102

[10] Marrero, M., Puerto, M., Rivero-Camacho, C., Freire-Guerrero, A. \& Solís-Guzmán, J. (2017). “ Assessing the economic impact and ecological footprint of construction and demolition waste during the urbanization of rural land" . Resources, Conservation and Recycling $117.160-174$ https://doi.org/10.1016/j.resconrec.2016.10.020

[11] Tran, D. Q., Hallowell, M. R., \& Molenaar, K. R. (2014). “Construction Management Challenges and Best Practices for Rural Transit Projects" . American Society of Civil Engineers. DOI: 10.1061/(ASCE)ME.1943-5479.0000297

[12] Qi, Z. \& Li, G. (2010). "Contributions and Constraints of Rural Household Biogas Construction Project in Northeast China” . Institute of Electrical and Electronics Engineers. https://doi.org/10.1109/ICMSS.2010.5576785

[13] Lin, Z. \& Wei, Y. (2011). "Pothook of Urban and Rural Construction Land Rationality Assessment: A Case of Hailong Village” . Institute of Electrical and Electronics Engineers.

[14] Gumindoga, W., Rientjes, T, M, H., Haile, A.T. \& Dube, T. (2014). “ Predicting streamflow for land cover changes in the Upper Gilgel Abay River Basin, Ethiopia: A TOPMODEL based approach" . Physics and Chemistry of the Earth 76 - 78 (2014) 3 - 15 https://doi.org/10.1016/j.pce.2014.11.012

[15] Ramli, M. Z., Malek, M, A., Hanipah, M, H., Lin, C, L., Mahamad Sukri, M, F., Zawawi, M, H., Zainal Abidin, M, Z. \& Mohamad Fuad, N, F, S,. (2017). "Study of factors influencing construction delays at rural area in Malaysia" . International PostGraduate Conference on Applied Science \& Physics. DOI :10.1088/1742-6596/1049/1/012017

[16] Zhenhua, L. (2013). "Supervision and Management Information System for Rural Drinking Water Project Construction” . Conference Publishing Services. Third International Conference on Intelligent System Design and Engineering Applications. DOI 10.1109/ISDEA.2012.325

[17] Yun-fei, H. \& Yun, C. (2009). "The Index System Construction of Preferential Evaluation for Investment and Financing Project on Rural Roads" . Institute of Electrical and Electronics Engineers; computer society. International Conference on Information Management, Innovation Management and Industrial Engineering. DOI 10.1109/ICIII.2009.416

[18] Berk, A. \& Akdemir, S. (2006). "Impact of rural development projects on rural areas in Turkey: A study on Yozgat rural development project" . Journal of applied sciences, 6(9): 1892-1899 https://doi.org/10.3923/jas.2006.1892.1899

[19] Zumrawi, M. (2014). "Effects of inadequate geotechnical investigations on civil engineering projects Effects of Inadequate Geotechnical Investigation on Civil Engineering Projects" Journal of applied sciences. Res. 3

[20] Usman, N. \& Ibrahim, A, M. (2015). "Challenges Associated With Remote Sites Project Management” . J. Multidiscip. Eng. Sci. Technol. 2 $3159-40$

[21] Chavada R., Dawood N.N. \& Kassem M. (2012). "Construction workspace management: The development and application of a novel $\mathrm{nD}$ planning approach and tool” . J. Inf. Technol. Constr. 213 - 36

[22] Sidawi, B. (2012). “Remote Construction Projects' Problems And Solutions" . The Case Of Sec 48th ASC Annual International Conference Proceedings (Associated Schools of Construction)

[23] Francis, J. J., Johnston, M., Robertson, C., Glidewell, L., Entwistle, V., Eccles, M. P., \& Grimshaw, J. M. (2010). What is an adequate sample size? Operationalising data saturation for theory-based interview studies. Psychology and Health, 25, 1229 - 1245. doi:10.1080/08870440903194015 